Gi respons på artikler gjennom artiklenes kommentarfelt på tidsskriftet.no.

Innleggene publiseres fortløpende på Tidsskriftets nettside og et utvalg

av innleggene publiseres også i papirutgaven i spalten «Brev til redaktøren».

Redaksjonen forbeholder seg retten til å foreta redaksjonelle endringer.

Forfattere av vitenskapelige artikler har tilsvarsrett, jf. Vancouver-gruppens regler.

\section{Re: Påvisning av spinalvæskelekkasje med farget klorheksidin}

Dette var en veldig flott og konsis artikkel (1), og det er flere som har lurt på det samme. Den refererte artikkelen i publikasjonen var også meget interessant lesning. I denne sammenhengen fortjener dr. Knudsens artikkel fra 2006 i Acta Anaesthesiologica en liten omtale (2). Her presenteres eksempler på mulig bruk av teknikken, slik som der hvor anestesilegen mistenker aksidentell perforasjon av dura ved innleggelse av epiduralkateter, og resultatene fra Knudsens forsøk på å finne årsakssammenhengen. Han kom også frem til at årsaken hadde sammenheng med at fenol er en svak syre som vil gjennomgå fargeforandring når $\mathrm{pH} ø$ øer. I artikkelen finner man et par fine bilder fra Knudsens forsøk samt en tabell over $\mathrm{pH}$ i noen relevante væsker som kan forveksles med spinalvæske i en klinisk hverdag.

\section{Håvard Landsdalen}

landsdalen@gmail.com

Håvard Landsdalen (f. 1984) er lege i spesialisering ved Haukeland universitetssykehus

Ingen oppgitte interessekonflikter.

\section{Litteratur}

1. Nilsbakken IMW, Karlsen LB, Jakobsen R. Påvisning av spinalvæskelekkasje med farget klorheksidin. Tidsskr Nor Legeforen 2014; 134: 2057.

2. Knudsen K. Coloured chlorhexidine cotton pads may help to identify cerebrospi nal fluid during epidural or spinal anaesthesia. Acta Anaesthesiol Scand 2006. 50: $685-7$

\section{Re: Påvisning av spinalvæskelekkasje med farget klorheksidin}

I denne artikkelen beskrives hvordan man kan påvise spinalvæske med farget klorheksidin (1). Jeg har prøvd dette på nasalt slim, og det ga nøyaktig samme fargeomslag som spinalvæsken gjorde. Jeg får inntrykk av at forfatterne her prøver å fortelle at leger bør bruke dette på pasienter for å avgjøre hvem som har et livstruende skallebrudd, uten at det kommenteres at det er ikke finnes vitenskapelig bevis som støtter at metoden kan brukes i praksis.

Dette er et gammelt triks med ukjent betydning. Det må gjøres studier med hodeskadepasienter for å se om metoden virkelig kan brukes diagnostisk.

\section{Hjalti Björnsson}

hjaltimb@landspitali.is

Hjalti Björnsson (f. 1972) er akuttlege ved Landspitali, Reykjavik, Island. Ingen oppgitte interessekonflikter.

Litteratur

1. Nilsbakken IMW, Karlsen LB, Jakobsen R. Påvisning av spinalvæskelekkasje med farget klorheksidin. Tidsskr Nor Legeforen 2014; 134: 2057.

\section{L.B. Karlsen og medarbeidere svarer:}

Takk for kommentarer fra Landsdalen og Björnsson!

Vi har i ettertid blitt gjort oppmerksomme på Dr. Knudsens publikasjon fra 2006, der han presenterer sammenhengen mellom $\mathrm{pH}$ i spinalvæske og fenolrødt. Vi beklager at vi ved litteratursøk ikke fant denne første beskrivelsen, som selvsagt skulle vært referert til.
Vi er fullt klare over at metoden er uspesifikk. Den må dermed brukes og ses i sammenheng med pasientens kliniske tilstand, andre diagnostiske metoder og skadeomfanget. Vi tenker at metoden har størst nytte pre- og intrahospitalt for å gi en pekepinn om videre behandling og om profylaktisk antibiotikabehandling er nødvendig før andre prøvesvar foreligger. Metoden er heller ikke tenkt å skulle erstatte de vanlige testene for spinalvæskelekkasje, men å være et raskt, billig og enkelt supplement.

Vi er helt enige $\mathrm{i}$ at metoden må forskes ytterligere på for å kunne bestemme dens sensitivitet og spesifisitet, og da fortrinnsvis på hodeskaepasienter.

\section{Linnea Berg Karlsen \\ bergkarlsen@hotmail.com \\ Inger Marie Waal Nilsbakken \\ Raymond Jakobsen}

Linnea Berg Karlsen (f. 1994) er medisinstudent ved Universitetet

i Troms $\varnothing$ - Norges arktiske universitet.

Ingen oppgitte interessekonflikter.

Inger Marie Waal Nilsbakken (f. 1993) er medisinstudent ved Universitetet i Troms $\varnothing$ - Norges arktiske universitet.

Ingen oppgitte interessekonflikter.

Raymond Jakobsen (f. 1976) er spesialbioingeniør ved Universitetssykehuset Nord-Norge.

Ingen oppgitte interessekonflikter.

\section{Re: Arbeidsmiljøet gir fremdeles sykdom}

Takk til forfatterne, som med denne lederen bidrar til å minne oss om legers viktige rolle for å forebygge arbeidsbetinget sykdom, herunder kartlegging av arbeidsplassen (1). Dette bør også være tilfellet for hudsykdommer, men dessverre synes det som betydningen av arbeidsbetingede hudsykdommer får mindre oppmerksomhet i Norge sammenlignet med våre naboland (2). Er det fordi de ikke representerer et problem i norsk arbeidsliv, eller er det ford vi vet for lite om forekomsten av arbeidsbetingede hudsykdommer i Norge? Epidemiologiske studier innen arbeidsrelaterte og -betingede hudsykdommer har ikke vært gjennomført i samme omfang som tilsvarende studier eksempelvis innen lungesykdommer. Den siste norske doktorgraden om arbeidsbetinget hudsykdom er 20 år gammel (3).

Vår innsikt $i$ arbeidsbetingede hudsykdommer kommer hovedsakelig fra studier gjennomført i andre land, og da gjerne studier av selekterte grupper av pasienter, lappetestdatabaser og offisielle yrkessykdomsregistre (2). Dette er ikke nok for å forstå lokale forhold, siden sammenligningen er begrenset av forskjeller mellom landene $\mathrm{i}$ både eksponering og rapportering.

Det kroniske forløpet av arbeidsrelaterte hudsykdommer, som i hovedsak utgjøres av irritativt og allergisk kontakteksem på hender, resulterer i uheldige samfunnsøkonomiske konsekvenser på grunn av tap av arbeidsevne og uførhet. Kostnadene er beregnet til å overstige 5 milliarder $€$ / år i EU-området gjennom tap av produktivitet (2). EU-kommisjonen har nylig definert at manglende forebygging av arbeidsbetingede hudsykdommer er et samfunnsmessig problem som må prioritereres (2), og av WHO som en utfordring for arbeidstakeres helse (2). 